\title{
Sorption of Heavy Metals by Ferralic-Arenosol and Vertic-Luvisol: A Comparative Isothermal Study
}

\author{
Tlou Mosekiemang ${ }^{1}$, Oagile Dikinya $^{2}$ \& Elisha Toteng ${ }^{2}$ \\ ${ }^{1}$ Department of Chemistry, University of Botswana, Gaborone, Botswana \\ ${ }^{2}$ Department of Environmental Science, University of Botswana, Gaborone, Botswana \\ Correspondence: Tlou Mosekiemang, Department of Environmental Science, University of Botswana, Gaborone, \\ Botswana. Tel: 267-355-2527. E-mail: mosekiemang@mopipi.ub.bw
}

\author{
Received: December 31, 2013 Accepted: January 15, 2014 Online Published: February 26, 2014 \\ doi:10.5539/ep.v3n2p23 \\ URL: http://dx.doi.org/10.5539/ep.v3n2p23
}

The research was financed by the Department of Training and Development, University of Botswana through a scholarship grant awarded to the lead author. Other financial assistance worth acknowledging was received from Mr Evans Monowe through Monowe Abattoirs (PTY) LTD's social responsibility initiative

\begin{abstract}
Modeling of sorption data is essential for characterizing retention of heavy metals by the soil matrices as well as to predict the fate of heavy metals in the environment. We carried out a study to evaluate adsorption characteristics of metallic ions $\left(\mathrm{Cr}^{3+}, \mathrm{Pb}^{2+}\right.$ and $\left.\mathrm{Cu}^{2+}\right)$ as sole sorbates as well as in coexistence onto clay extracts of Vertic-Luvisol and Ferralic-Arenosol, the generally under-researched yet wide-spread semi-arid soils. Additionally, sorption kinetics of these heavy metals was evaluated in these soils. Equilibrium sorption data for both non-competitive and competitive metal systems were found to obey the Langmuir isotherm. Overall metal loading capacity was higher in Vertic-Luvisol than Ferralic-Arenosol whereas metal-wise affinity to binding sites favoured sorption of $\mathrm{Cr}^{3+}$ over $\mathrm{Pb}^{2+}$ and $\mathrm{Cu}^{2+}$ in that order. Contrary to the hypothesis of this study, the preferential sorption process was found to be driven by cationic properties as opposed to soil properties. Adsorption of metallic ions onto soils was significantly reduced in competitive systems than non-competitive systems, a phenomenon attributable to the antagonistic effects of coexisting species. $\mathrm{Cr}^{3+}$ suppressed sorption of $\mathrm{Pb}^{2+}$ and $\mathrm{Cu}^{2+}$ on both soils as validated by the competitive adsorption capacity ratios which were $<1$ in all instances where $\mathrm{Cr}^{3+}$ coexisted with either one of $\mathrm{Pb}^{2+}$ or $\mathrm{Cu}^{2+}$. The adsorption kinetics of metal ions in both soils followed the pseudo-second-order rate law, suggesting chemical sorption as the rate-limiting step of the adsorption process.
\end{abstract}

Keywords: adsorption isotherms, adsorption kinetics, binary-metal system, mono-metal system

\section{Introduction}

The ability of soils to adsorb metal ions is of special interest and has consequences both for agricultural production and environmental remediation. With the current awareness of heavy metals as very toxic contaminants there have been many studies considering adsorption by solid surfaces as the most important mechanism for controlling metal content in soil solution and natural waters (Echeverria, Morera, Mazkiaran, \& Garido, 1998; Bradl, 2004; Appel, Ma, Rhue, \& Reve 2008; Javaid, Bajwa, Shafique, \& Anwar, 2011). The most important chemical processes affecting the behavior and bioavailability of heavy metals in soils are those concerned with sorption mechanisms of metals from liquid phase onto solid phase (Rybicka, Calmano, \& Breeger, 1995; Covelo, Andrade, \& Vega, 2004). Moreover, clay minerals and to a lesser extent organic matter have been identified as among the major soil constituents that interact with almost all soil contaminants especially positively charged metallic species. Thus, clays often represent a short-term sink of heavy metals in soils, a trait attributable to their adsorptive properties. The heavy metal bearing component of the soil, which in the perspective of this study is the clay mineral, can be a good and reliable indicator of environmental pollution. Clay minerals play an important role in accumulation, adsorption/desorption, as well as exchange processes of metal ions (Wahba \& Zaghloul, 2007). In general, heavy metal retention depends on the type of clay minerals contained in the soil. It is well known that basic soil characteristics influencing the sorption of metals, amongst 
others, depends on contents of organic matter, clay, Fe and Mn oxides and hydroxides, and carbonates (Bradl, 2004; Usman, 2008; Irha, Steinnes, Kirso, \& Petersell, 2009).

In order to describe the adsorption characteristics of adsorbates, experimental equilibrium data are most frequently modeled by the relationships developed by Freundlich and Langmuir (Echeverria et al., 1998; Limousin, Gaudet, Charlet, Szeknect, Barthes \& Krimissa, 2007; Gomes, Cavaco, Quina, \& Gando-Ferreira, 2010). Usually, the experimental approach involving sorption of sorbates onto sorbents is to gather data and produce adsorption isotherms, which are in turn interpreted to explain adsorption process. Analysis of sorption data is important for characterizing retention of contaminants by soil (Hinz, 2001) and in particular the Langmuir and Freundlich models are the most suitable for describing single solute adsorption of heavy metals to soils (Hinz, Gaston, \& Selim, 1994; Bolster \& Hornberger, 2007). The Langmuir and Freundlich isotherms are widely used since they have an ability to describe experimental results across a wide range of experimental adsorption data. These isotherm models can be transformed into linear forms to obtain adjustable parameters by graphical means or by linear regression analysis (Altin, Ozbelge, \& Dogu, 1998). The analysis of isotherms may provide useful information about the retention capacity and the sorption strength by which sorbate is held onto the soil (Sipos, Nemeth, Kis, \& Mohai, 2009).

The present contribution of this work is to provide information on heavy metal sorption characteristics of Vertic-Luvisol and Ferralic-Arenosol, the two dominant soil types in the semi-arid region of the world. These two soil types, especially Arenosols are among the under researched yet significantly wide-spread in the semi-arid region of the world (Ngole \& Ekosse, 2008; Mosekiemang \& Dikinya, 2012). According to Hartemink and Huting (2008), the total extent of Arenosols in the semi-arid regions covers approximately 273 million ha in the southern and western part of Africa. To this end, arenosols have not attracted much attention in research because of the many inherent attributes unfavourable for productive agriculture (Moroke, Dikinya, \& Patrick, 2009). Thus the main aims of this study were (1) to investigate sorption characteristics of $\mathrm{Cr}^{3+}, \mathrm{Cu}^{2+}$ and $\mathrm{Pb}^{2+}$ ions as single adsorbates in solution as well as when they are in coexistence in solution, (2) to use sorption isotherms, particularly Langmuir and Freundlich models to determine the sorption capacity in the two types of clay extracts in view of assessing their vulnerability to pollution and (3) to evaluate the sorption kinetics of these selected heavy metals in these semi-arid soils. As a rule, soil properties and composition differ with soil type and it is logical to expect variations in heavy metal sorption characteristics of different soil types. Thus, the main hypothesis being tested is that heavy metal sorption may be influenced by soil type.

\section{Method}

\subsection{Site Description and Sample Preparations}

The soil samples used in this study were collected from Glen Valley Horticultural Project in Eastern Gaborone, Botswana lying between Latitudes $\left(24^{\circ} 35^{\prime} 23.56^{\prime \prime S}\right.$ and $\left.24^{\circ} 37^{\prime} 01.14^{\prime \prime S}\right)$ and Longitudes $\left(25^{\circ} 58^{\prime} 43.29^{\prime \prime} \mathrm{E}\right.$ and $\left.25^{\circ} 58^{\prime} 16.74 " \mathrm{H}\right)$. Typical soils are predominately Ferralic-Arenosols (GARo) and Vertic-Luvisol (ALVv) characterized by reddish loamy sands and dark grey clays (FAO, 1998), respectively. The soil samples were collected from the plough layer $(0-20 \mathrm{~cm})$ and/or Ap horizon $(\mathrm{FAO}, 1998)$, air dried, and passed through a 2-mm sieve. To separate and remove the clay component from the 2-mm soil fraction, the sieved soil was mixed with double distilled water and stirred with a motorized stirrer at $1000 \mathrm{rpm}$ overnight to concentrate the clay particles. The suspension was left to settle for $24 \mathrm{~h}$ and the top layer was subsequently decanted, filtered and dried in an oven at about $100^{\circ} \mathrm{C}$ to constant weight to obtain the clay extracts.

\subsection{Characterization of Parent Soil Samples and Clay Extracts}

The soil samples were analyzed for physico-chemical characteristics, including particle size distribution (sand \%, silt \%, clay \%), soil colour, $\mathrm{pH}$ and cation exchange capacity (CEC) using laboratory standard methods (Breitbart, 1988; van Reeuwijk, 1993 in Dikinya \& Areola, 2010). Clay extracts were further analyzed/scanned for morphological and chemical characteristics (Figure 1 and 2) using the Philips XL30 Environmental Scanning Electron Microscope/EDAX. Identification of primary and secondary minerals in the clay samples was achieved using a Philips PW 3710 X-Ray diffractometer operated at $40 \mathrm{kV}$ with a $\mathrm{Cu}$ anode radiation and a graphite monochromator. Subsequently, interpretation of data and diffractograms was achieved by Philips X'PERT graphics and identify software (2001 version). The surface area of clay extracts (GARo and ALVv) were measured with a Micromeritics FlowSorb (III) 2310 instrument using the BET single point method and $\mathrm{N}_{2}$ gas adsorption. 


\subsection{Adsorption Experiments}

Two equilibrium batch experiments were conducted to determine mono-metal and binary-metal adsorption characteristics of selected heavy metals $\left(\mathrm{Cr}^{3+}, \mathrm{Cu}^{2+}\right.$ and $\left.\mathrm{Pb}^{2+}\right)$ onto clay extracts of GARo and ALVv. In mono-metal experiment, single-metal solutions were prepared by adding $20 \mathrm{~mL}$ of one metal solution to a $50 \mathrm{~mL}$ propylene tubes containing $20 \mathrm{mg}$ of the soil mineral matrix (clay extract). In this experiment, concentrations of single-metal solutions were $0,2.5,5,10,25$ and $50 \mathrm{mg} / \mathrm{L}$ of each of $\mathrm{Cr}^{3+}, \mathrm{Cu}^{2+}$ and $\mathrm{Pb}^{2+}$ and were carried out separately for one metal at a time. In binary-metal experiment, simultaneous competitive sorption of metals onto soil mineral matrix (clay extracts) were studied through batch equilibration. Binary-metal solutions were prepared such that each solution contained equal proportions of the two co-existing metals at a ratio of 1:1. The pairing of metals in a binary-metal solutions were aimed at achieving every possible combination option available to pair any two of the three analytes $\left(\mathrm{Cr}^{3+}\right.$ with $\mathrm{Pb}^{2+} ; \mathrm{Cr}^{3+}$ with $\mathrm{Cu}^{2+}$ and $\mathrm{Cu}^{2+}$ with $\left.\mathrm{Pb}^{2+}\right)$. Similarly, for monometal experiment, six concentration levels of $0,2.5,5,10,25$ and $50 \mathrm{mg} / \mathrm{L}$ of each bimetal combination were maintained and sorption experiments were achieved by weighing $20 \mathrm{mg}$ of the soil mineral matrix (clay extract) into $50 \mathrm{~mL}$ propylene tubes and equilibrating with a $20 \mathrm{~mL}$ of a binary-metal solution. In both experiments (mono and binary-metal), the tubes were shaken in a horizontal shaker for $3 \mathrm{~h}$ at $25 \pm 2{ }^{\circ} \mathrm{C}$, a previously determined optimal equilibration time (Alumaa, Kirso, Petersell, \& Steinnes, 2002; Adebowale, Unuabonah, \& Olu-Owalabi, 2006; Ghorbel-Abid \& Trabeisi-Ayadi, 2011) followed by centrifuging at 3000 rpm for $20 \mathrm{~min}$ and subsequent filtration through a filter paper (Whatman No. 42) to obtain a clear filtrate. The filtrate $\mathrm{pH}$ was then selectively measured in the filtrate solution of mono-metal batch whereas the entire consignment was assayed for heavy metal concentration.

\subsection{Sorption Kinetics}

Batch equilibrium experiments described above were followed by another experiment setup to determine the sorption kinetics of $\mathrm{Cr}^{3+}, \mathrm{Cu}^{2+}$ and $\mathrm{Pb}^{2+}$ onto clay extracts of soils of interest (GARo and ALVv). In this experiment, just like in the batch experiments, both working temperature and solution-sorbent ratio were maintained at $25 \pm 2{ }^{\circ} \mathrm{C}$ and $1 \mathrm{~g} / \mathrm{L}$ respectively, whereas the metal ion concentration and $\mathrm{pH}$ were kept constant at $100 \mathrm{mg} / \mathrm{L}$ and $6.5 \pm 0.02$, respectively. To maintain solution's cationic composition and to avoid metal (hydro) oxide precipitation during the course of sorption experiments, solution's $\mathrm{pH}$ was kept within the desired range by adding either $\mathrm{NaOH}$ or $\mathrm{HCl}$ (Mettler Toledo $320 \mathrm{pH}$ meter). Adsorbate-adsorbent contact time was varied at different times within 0-400 min range by shaking the solutions at 100 min time interval for the time range described earlier. Shaking was achieved by using a Labcon temperature controlled horizontal shaker followed by centrifuging, filtering and subsequent assaying for heavy metal content. In all cases described above, assaying of heavy metal content was determined using a using flame atomic spectrophotometer (Varian, SpetrAA FS-220, Australia). Whereas all chemicals used in this work were analytical reagent quality: $\mathrm{Pb}\left(\mathrm{NO}_{3}\right)_{2} ; \mathrm{Cu}\left(\mathrm{NO}_{3}\right)_{2} \cdot 2.5 \mathrm{H}_{2} \mathrm{O}$; $\mathrm{CrCl}_{3} \cdot 6 \mathrm{H}_{2} \mathrm{O} \mathrm{NaOH}$ and $\mathrm{HCl}$ were supplied by Sigma-Aldrich, South Africa.

\subsection{Data Analysis}

In the case of batch equilibrium studies, the amount of adsorption at equilibrium $Q_{e}(\mathrm{mg} / \mathrm{g})$, was calculated by:

$$
Q_{e}=\left(C_{0}-C_{e}\right) \times \frac{V}{m}
$$

where $C_{0}$ and $C_{e}(\mathrm{mg} / \mathrm{L})$ are liquid-phase concentrations of adsorbates $\left(\mathrm{Cr}^{3+}, \mathrm{Cu}^{2+}\right.$ and $\left.\mathrm{Pb}^{2+}\right)$ at initial and equilibrium, respectively. $\mathrm{V}$ is the volume of the solution $(\mathrm{L})$ and $\mathrm{m}$ is the mass of adsorbent (clay extract) used $(\mathrm{kg})$. In batch kinetic studies, the amount of adsorption of metal ions at time $(t), q_{t}(\mathrm{mg} / \mathrm{kg})$, was calculated by:

$$
q_{t}=\left(C_{0}-C_{e}\right) \times \frac{V}{m}
$$

where $C_{0}$ and $C_{e}(\mathrm{mg} / \mathrm{L})$ are the liquid-phase concentrations of adsorbates $\left(\mathrm{Cr}^{3+}, \mathrm{Cu}^{2+}\right.$ and $\left.\mathrm{Pb}^{2+}\right)$ at initial and any time $t$, respectively. Parameters $\mathrm{V}$ and $\mathrm{m}$ are similar to Equation 1.

\subsubsection{Single-Metal Sorption Isotherms}

The amounts of $\mathrm{Cr}^{3+}, \mathrm{Cu}^{2+}$ and $\mathrm{Pb}^{2+}$ adsorbed were fitted to the Langmuir (Equation 3) and Freundlich (Equation 5), respectively. The general Langmuir sorption model is expressed as follows;

$$
Q_{e}=\frac{Q_{\max } b C_{e}}{1+b C_{e}}
$$

where $Q_{e}$ is the uptake of the metal ion by the clay extract $(\mathrm{mg} / \mathrm{kg}), Q_{\max }$ is the upper limit of $Q_{e}$ which represents maximum uptake (adsorption maxima) of the clay extract $(\mathrm{mg} / \mathrm{kg}) . C_{e}$ is the equilibrium concentration of metal ions in solution $(\mathrm{mg} / \mathrm{L})$ and $b$ is the Langmuir adsorption constant. This model implies that saturation of the adsorptive sites is possible, and ideally $Q$ can eventually reach a maximum value $\left(Q_{\max }\right)$. Therefore parameters 
$Q_{e}$ and $C_{e}$ can be experimentally determined whereas $Q_{\max }$ and $b$ can either be calculated from least-square fitting or a simple plot of a linearized form of Equation 3 which yields;

$$
\frac{C_{e}}{Q_{e}}=\frac{1}{Q_{\max b}}+\frac{C_{e}}{Q_{\max }}
$$

A plot of $\frac{C_{e}}{Q_{e}}$ vs $c_{e}$ gives a linear plot with the slope of $\frac{1}{Q_{\max }}$ and intercept of $\frac{1}{Q_{\max } b}$

The general form of the Freundlich Equation is:

$$
Q_{e}=k_{F} C_{e}^{1 / n}
$$

where $Q_{e}$ and $C_{e}$ are the same as in Equation 3, and $k_{F}$ and $n$ relate to the capacity and intensity of adsorption, respectively. The Freundlich model is based on sorption of metal ions on heterogeneous surface and can be linearized by taking logarithms:

$$
\log Q_{e}=\log k_{F}+\frac{1}{n} \log C_{e}
$$

where the parameters $k_{F}$ and $n$ are determined similarly to the Langmuir case.

\subsubsection{Binary-System Sorption}

The mutual interference effects of binary-metal ions $\left(\mathrm{Cr}^{3+}-\mathrm{Pb}^{2+} ; \mathrm{Cr}^{3+}-\mathrm{Cu}^{2+}\right.$ and $\left.\mathrm{Cu}^{2+}-\mathrm{Pb}^{2+}\right)$ on sorption dynamics were probed using competitive adsorption capacity ratios (CACR) for the two adsorption isotherms under study. According to Qin et al. (2006); Mahamadi and Nharingo (2010) and Zhu, Hu and Wang, (2012), $Q_{\text {max }}{ }^{\prime} Q_{\max }$ and $k_{F}^{\prime} / k_{F}$ represents CACR for the Langmuir and Freundlich equations, respectively. The isotherm constants, $Q_{\max }$ and $Q_{\max }$ indicate the Langmuir adsorption capacity in single and binary system, while $k_{F}$ and $k_{F}$ are the Freundlich adsorption capacity of singe metal solution and in the presence of the other metal, respectively. The value of $Q_{\max } / Q_{\max }$ and $k_{F} / k_{F}$ has implications on the effect of mixing metals in a solution; synergistic $\left(Q_{\max }^{\prime} / Q_{\max }\right.$ and $\left.k_{F}^{\prime} / k_{F}>1\right)$; no net interaction $\left(Q_{\max }^{\prime} / Q_{\max }\right.$ and $\left.k_{F}^{\prime} / k_{F}=1\right)$; or antagonistic $\left(Q_{\max }^{\prime} / Q_{\max }\right.$ and $k_{F}^{\prime} / k_{F}$ $<1)$.

\subsubsection{Sorption Kinetics}

In order to study adsorption kinetics, various rate equations (first-order, second-order and inter-particle diffusion) were applied to the time-dependent kinetic data in order to obtain rate coefficients. The pseudo-first order (Lagergren 1898, in Argun, Dursun, Ozdemir, \& Karatas, 2007), Equation (7); pseudo-second order, Equation (8) and inter-particle diffusion, Equation (9) are expressed as follows:

$$
\begin{gathered}
\log \left(q_{e}-q_{t}\right)=\left(\log q_{e}\right)-k_{1} t \\
\frac{d q_{e}}{d_{t}}=k_{2}\left(q_{e}-q_{t}\right)^{2} \\
q_{t}=k_{i} t^{1 / 2}+C
\end{gathered}
$$

where $q_{t}$ is the metal uptake per unit weight clay $(\mathrm{mg} / \mathrm{g})$ at the time $t, q_{e}$ is the metal uptake per unit weight of clay $(\mathrm{mg} / \mathrm{g})$ at equilibrium, and $\mathrm{k}_{1}\left(\mathrm{~min}^{-1}\right)$ and $\mathrm{k}_{2}(\mathrm{~g} / \mathrm{mg} / \mathrm{min})$ are the rate constants of the first-order and pseudo second order kinetic equations, respectively. $C(\mathrm{mg} / \mathrm{g})$ and $k_{i}\left(\mathrm{mg} \mathrm{g}^{-1} \mathrm{~h}^{-1 / 2}\right)$ are the equation's constant and intra-particle diffusion rate constant, respectively. Linearized plots of Equations. (7-9), $\log \left(q_{e}-q_{t}\right)$ vs $\mathrm{t}$ (pseudo-first order), $\mathrm{t} / \mathrm{q}_{\mathrm{t}}$ vs $\mathrm{t}$ (pseudo-second order) and $q_{\mathrm{t}} \mathrm{vs}^{\mathrm{t} / 2}$ (intra-particle diffusion) were used to identify the best kinetic model that describe sorption kinetics of $\mathrm{Cr}^{3+}, \mathrm{Cu}^{2+}$ and $\mathrm{Pb}^{2+}$ on clay adsorbents. The choice of the best kinetic model was based on superiority of the $r^{2}$ correlation coefficient for linearity of the plots.

\section{Results}

\subsection{Soil Morphology, Classification and Physico-Chemical Properties}

The morphological features of the soil samples are presented in Table 1. These soils were classified according to the FAO (1998) - world reference base for soil resources as Vertic Luvisol (ALVv) and Ferralic Arenosol (GARo), respectively. For GARo, the colour of the top (Ap) horizon was 5YR hue with value 4-6 and chroma 4 to 8 and predominantly red. While ALVv was predominantly grey along with a 10YR hue with value 2 to 3 and chroma 1 to 4 . Laboratory analyses supported field observations. Texture of the soil samples ranged between sandy clay loam and sandy loam for ALVv and GARo, respectively. ALVv had the highest clay content and the least $\mathrm{pH}$ value whereas GARo had the least clay content and highest $\mathrm{pH}$ value. The $\mathrm{CEC}$ values ranged between 33.08 to $61.54 \mathrm{cmol} / \mathrm{kg}$ for GARo and ALVv, respectively. The high CEC values were contributed largely by 2:1 swelling clays (Sposito, 1984). 
Table 1. The physico-chemical properties of the soils

\begin{tabular}{lll}
\hline Clay type & Parameter & Description \\
\hline \multirow{3}{*}{ GARo } & Colour & Red (5YR 4/6 - 4/8) \\
& Mineral Composition (\%) & Ferrosilite magnesian (26); hematite (58); Quartz (16) \\
& Specific surface area & $212 \mathrm{~m}^{2} \mathrm{~g}^{-1}$ \\
& Cation Exchange Capacity & $33.08 \mathrm{cmol} / \mathrm{kg}$ \\
& $\mathrm{pH}-\left(\mathrm{H}_{2} \mathrm{O}\right)$ & 7.49 \\
& Clay(\%) / Silt(\%) / Sand (\%) & $28.2 \% / 14.5 \% / 57.3 \%$ \\
\hline \multirow{3}{*}{$\mathrm{ALVv}$} & Colour & Grey (10YR 2/3-1/4) \\
& Mineral Composition (\%) & Smectite (31); Clintonite (30); Kaolinite (22); Quartz (17) \\
& Specific surface area & $362 \mathrm{~m}^{2} \mathrm{~g}^{-1}$ \\
& Cation Exchange Capacity & $61.54 \mathrm{cmol} / \mathrm{kg}$ \\
& $\mathrm{pH}-\left(\mathrm{H}_{2} \mathrm{O}\right)$ & 7.35 \\
& Clay $(\%) /$ Silt(\%) / Sand (\%) & $35.5 \%$ / 16.0\% / 48.5\% \\
\hline
\end{tabular}

\subsection{Morphological Characteristics of Clay}

According to the electron microscope micrographs, ALVV clay particle morphology was platy and less porous (Figure 1) than that of GARo (Figure 2) which was more spherical, porous and exhibited the tendency to conglomerate as shown in the $500 \times$ micrograph. The primary clay minerals contained in ALVv were smectite, kaolinite and quartz whereas GARo contained significant amounts of hematite and quartz (Ngole \& Ekosse, 2008). Nonetheless, the diagnostic rod shape entities which are symptomatic to the presence of hematite were visible in the 5000× magnification of Figure 2, and traces of platy entities indicative of the presence of smectite were visible in the 5000× magnification of Figure 1 . The nature of clay mineral has profound effects on the adsorptive capacity and heavy metal retention of soils, with smectite and kaolinite (the typical 2:1 swelling clays) having relatively larger surface area and adsorptive capacity than hematite - a distinctive 1:1 clay (see Table 1). The bulk chemical composition of the two clay types was dominated by $\mathrm{SiO}_{2}$ and $\mathrm{Al}_{2} \mathrm{O}_{3}$ which made up $66.6 \%$ and $31.3 \%$, respectively in ALVv and $69.5 \%$ and $11.2 \%$, respectively in GARo (Table 2). However, GARo had a higher $\mathrm{Fe}_{2} \mathrm{O}_{3}$ content than ALVv corroborating the presence of hematite (an Fe rich mineral). Losses Due to Ignition (\%LDI), which was indicative of the presence of volatiles were negligibly low at $0.03 \%$ and $2.5 \%$ for ALVv and GARo, respectively.
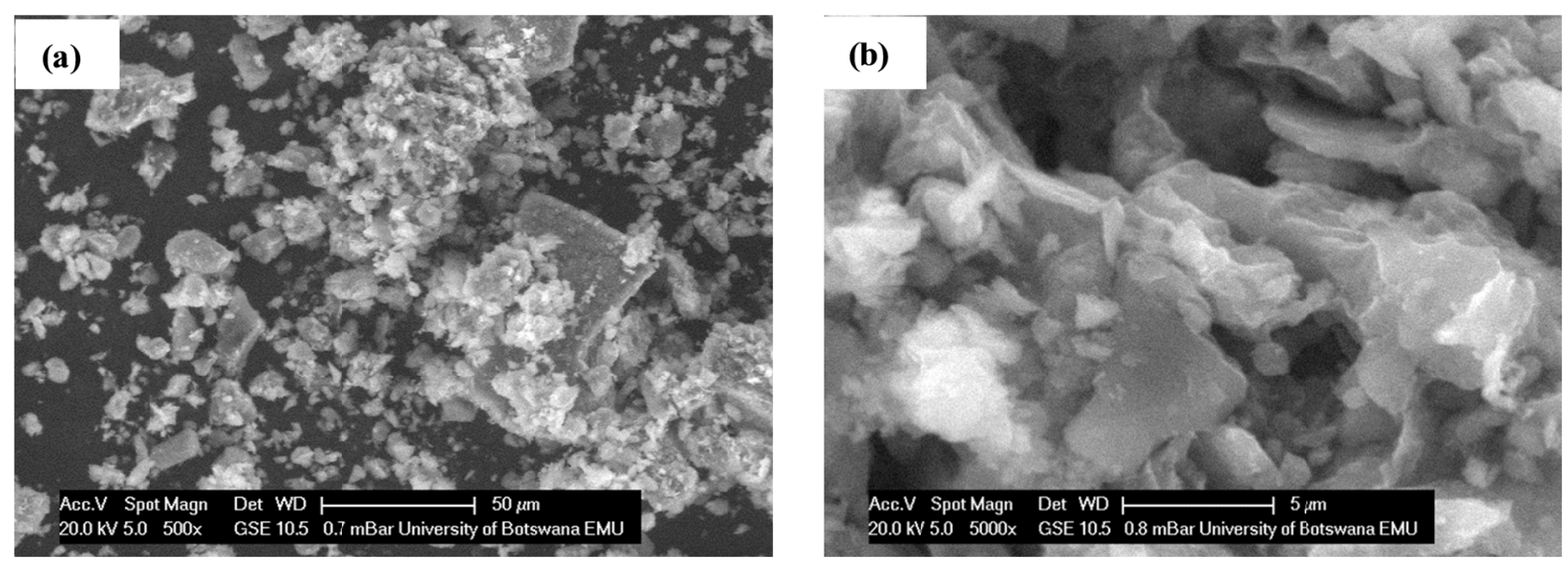

Figure 1. SEM photomicrographs of ALVv under (a) $500 \times$ and (b) $5000 \times$ magnifications 

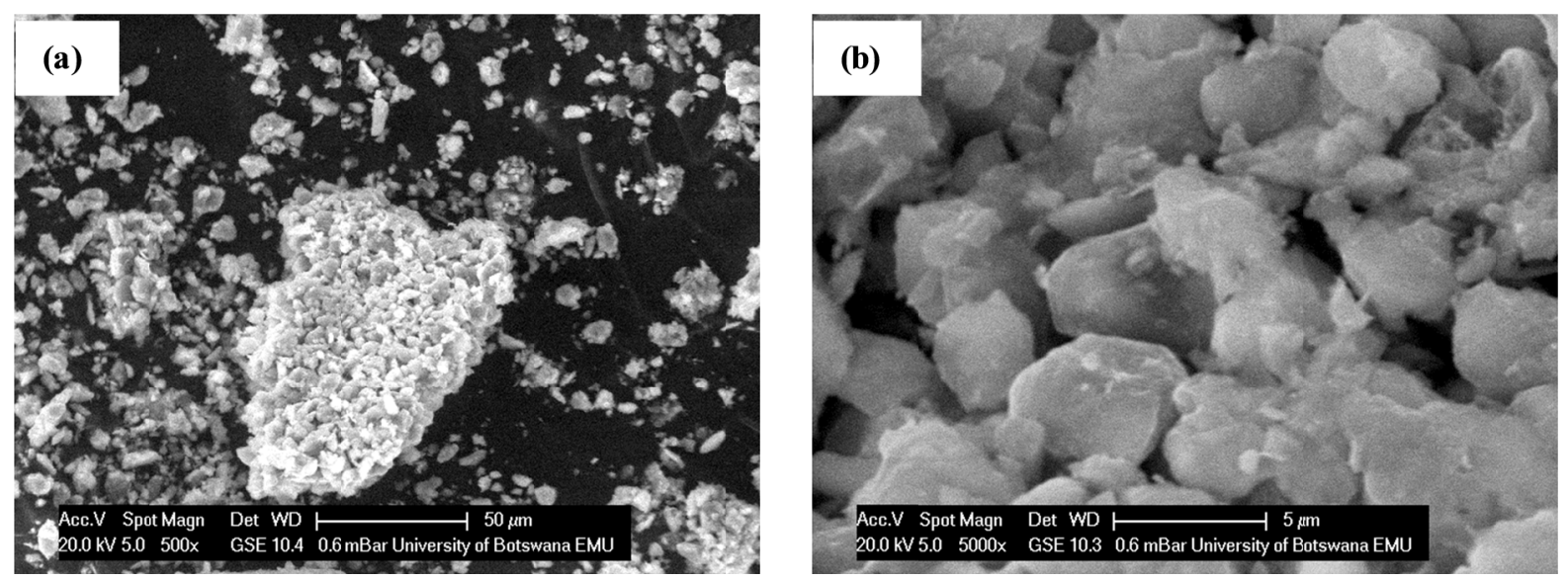

Figure 2. SEM photomicrographs of GARo under (a) $500 \times$ and (b) $5000 \times$ magnifications

Table 2. Chemical composition of clay extracts

\begin{tabular}{clllllllllll}
\hline & \multicolumn{10}{c}{ Mineral Composition (\%) } \\
\cline { 2 - 11 } Clay extract & $\mathrm{SiO}_{2}$ & $\mathrm{Al}_{2} \mathrm{O}_{3}$ & $\mathrm{Fe}_{2} \mathrm{O}_{3}$ & $\mathrm{MnO}$ & $\mathrm{MgO}$ & $\mathrm{CaO}$ & $\mathrm{Na}_{2} \mathrm{O}$ & $\mathrm{K}_{2} \mathrm{O}$ & $\mathrm{TiO}_{2}$ & $\mathrm{P}_{2} \mathrm{O}_{5}$ & Total \\
\hline ALVv & 66.6 & 31.3 & 0.9 & 0.3 & $<\mathrm{d} .1$ & $<\mathrm{d} .1$ & $<\mathrm{d} .1$ & 0.3 & 0.3 & $<$ d.1 & $99.7^{\mathrm{a}}$ \\
GARo & 69.5 & 11.2 & 10.5 & $<$ d.1 & $<$ d.1 & $<$ d.1 & $<$ d.1 & 3.7 & 2.6 & $<$ d.1 & $97.5^{\mathrm{b}}$ \\
\hline
\end{tabular}

d.l $=$ detection limit; ${ }^{\mathrm{a}} \mathrm{LDI}=0.03 \% ;{ }^{\mathrm{b}} \mathrm{LDI}=2.5 \%$.

\subsection{Adsorption Isotherms of Single Metal System}

The graphical illustrations of the content of metal adsorbed onto solid phases as a function of incremental metal concentrations are shown in Figure 3, where $C_{e}$ and $Q_{e}$ are concentrations of dissolved and adsorbed metal forms, respectively. The isotherms of the soil types were identical in shape. They reached a well-defined plateau at high metal ion concentration ( $\pm 40 \mathrm{mg} / \mathrm{L}$ ) and were of type-L, based on the classification described by Giles, McEvan, Nakhawa and Smith (1960). These types of isotherms are characterized by decreasing slopes as equilibrium concentration of metal ions increases. This phenomenon is attributable to high affinity of the sorbent at low concentration of sorbates in solution.

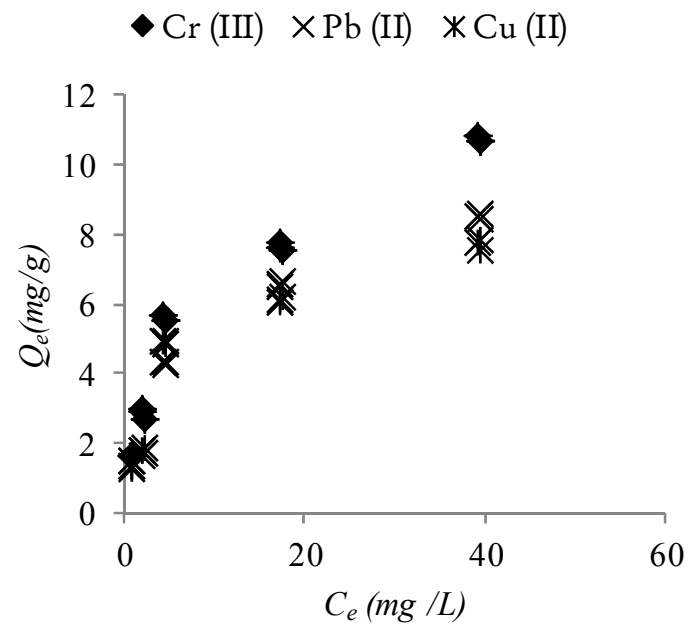

(a) Vertic-Luvisol

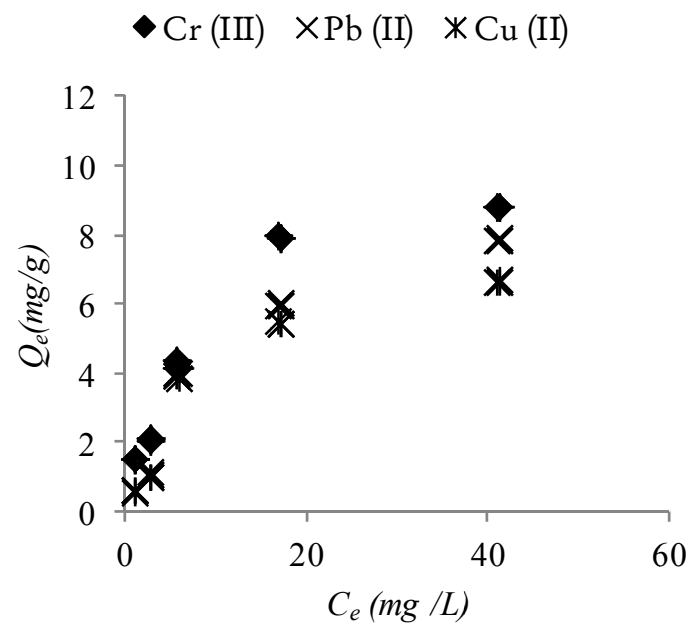

(b) Ferralic-Arenosol

Figure 3. Equlibrium adsorption isotherms of $\mathrm{Cr}^{3+}, \mathrm{Cu}^{2+}$ and $\mathrm{Pb}^{2+}$ ions onto $\mathrm{ALVv}$ and GARo clays in a mono-metal system. $C_{e}$ is the concentration of metalic ions in equilibrium, and $Q_{e}$ is the adsorption 
Augmentation of metal ions in contact with solid phases resulted in significant acidification of the systems as shown in Figure 4. In both soils, the initial $\mathrm{pH}$ was circum-neutral then dropped to \pm 4.5 when the solid phases approched saturation.

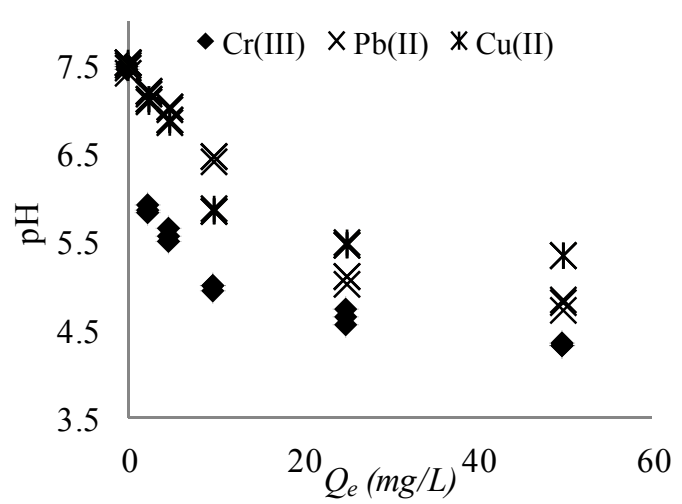

(a) Vertic-Luvisol

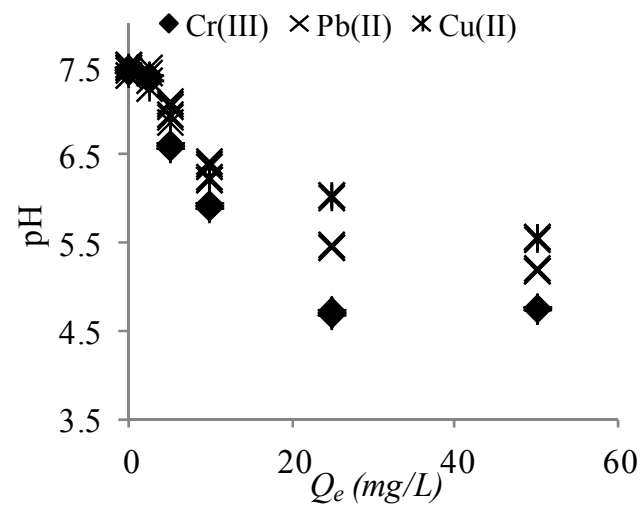

(b) Ferra lic-arenosol

Figure 4. Resultant equlibrium solution's $\mathrm{pH}$ as a function of incremental metal ion concentration interacting with the solid phases

\subsection{Isothermal Data Fitting}

\subsubsection{Monometal System}

The experimental data for the uptake of $\mathrm{Cr}^{3+}, \mathrm{Pb}^{2+}$ and $\mathrm{Cu}^{2+}$ were processed in accordance with two most widely used Langmuir and Freundlich classical adsorption isotherms. The results of regression analysis for calculating the parameters of Langmuir and Freundlich models are presented in Table 3.

Table 3. Langmuir and Freundlich isothermal parameters in mono-metal systems

\begin{tabular}{|c|c|c|c|c|}
\hline \multirow[b]{2}{*}{ Clay type } & \multicolumn{4}{|c|}{ The Langmuir isotherm constants } \\
\hline & Metal ion $(n)^{\mathrm{a}}$ & $b\left(\mathrm{~L} \mathrm{mg}^{-1}\right)$ & $Q_{\max }\left(\mathrm{mg} \mathrm{g}^{-1}\right)$ & $r^{2}$ \\
\hline \multirow[t]{3}{*}{ ALVv } & $\mathrm{Cr}^{3+}(10)$ & $3.1 \pm 0.9$ & $32.2 \pm 3.1$ & 0.9824 \\
\hline & $\mathrm{Cu}^{2+}(10)$ & $1.2 \pm 1.1$ & $12.2 \pm 2.1$ & 0.9679 \\
\hline & $\mathrm{Pb}^{2+}(9)$ & $2.1 \pm 3.1$ & $28.6 \pm 2.5$ & 0.9477 \\
\hline \multirow[t]{4}{*}{ GARo } & $\mathrm{Cr}^{3+}(8)$ & $2.8 \pm 2.1$ & $10.4 \pm 1.9$ & 0.9863 \\
\hline & $\mathrm{Cu}^{2+}(10)$ & $0.8 \pm 2.4$ & $6.85 \pm 2.1$ & 0.9563 \\
\hline & $\mathrm{Pb}^{2+}(10)$ & $1.1 \pm 0.7$ & $9.37 \pm 2.4$ & 0.9645 \\
\hline & \multicolumn{4}{|c|}{ The Freundlich isotherm constants } \\
\hline Clay type & Metal ion $(n)$ & $k_{F}\left(\mathrm{mg} \mathrm{g}^{-1}\right)$ & $n$ & $r^{2}$ \\
\hline \multirow[t]{3}{*}{$\mathrm{ALVV}$} & $\mathrm{Cr}^{3+}(9)$ & $42.0 \pm 0.4$ & $0.67 \pm 0.01$ & 0.9442 \\
\hline & $\mathrm{Cu}^{2+}(10)$ & $29.4 \pm 0.9$ & $0.45 \pm 0.01$ & 0.8619 \\
\hline & $\mathrm{Pb}^{2+}(9)$ & $16.4 \pm 0.3$ & $0.31 \pm 0.01$ & 0.9114 \\
\hline \multirow[t]{3}{*}{ GARo } & $\mathrm{Cr}^{3+}(10)$ & $30.5 \pm 0.7$ & $0.59 \pm 0.01$ & 0.9472 \\
\hline & $\mathrm{Cu}^{2+}(10)$ & $18.9 \pm 1.1$ & $0.51 \pm 0.01$ & 0.9210 \\
\hline & $\mathrm{Pb}^{2+}(9)$ & $11.7 \pm 0.9$ & $0.62 \pm 0.01$ & 0.9324 \\
\hline
\end{tabular}

$(n) *$ denotes the number of experimental points in the isotherm. 


\subsubsection{Binary-Metal System}

The mutual interference effects of binary-metal ions $\left(\mathrm{Cr}^{3+}-\mathrm{Pb}^{2+} ; \mathrm{Cr}^{3+}-\mathrm{Cu}^{2+}\right.$ and $\left.\mathrm{Cu}^{2+}-\mathrm{Pb}^{2+}\right)$ on sorption as well as single and binary-metal isothermal parameters are presented in Table 4. The results indicate that overall adsorption capacity was significantly decreased by mutual coexistence of competing species (Antoniadis, Tsadilas, \& Ashworth, 2007).

Table 4. Mono-metal and binary-metal systems isothermal parameters

\begin{tabular}{|c|c|c|c|c|c|c|c|c|c|c|}
\hline \multirow{3}{*}{$\begin{array}{l}\text { Clay } \\
\text { ALVv }\end{array}$} & \multirow[t]{3}{*}{ Metal } & \multirow[t]{3}{*}{ System } & \multirow[t]{2}{*}{$k_{F}{ }^{\prime} / k_{F}$} & \multirow[t]{2}{*}{$Q_{e}{ }^{\prime} Q_{e}$} & \multicolumn{6}{|c|}{ Isotherms } \\
\hline & & & & & \multicolumn{3}{|c|}{ Langmuir } & \multicolumn{3}{|c|}{ Freundlich } \\
\hline & & & & & $b$ & $Q_{\max }$ & $r^{2}$ & $k_{F}$ & $n$ & $r^{2}$ \\
\hline & - & $\mathrm{Cr}^{3+}$ & - & - & $3.1 \pm 0.9$ & $32.2 \pm 3.1$ & 0.982 & $42.0 \pm 0.4$ & 0.67 & 0.944 \\
\hline & - & $\mathrm{Pb}^{2+}$ & - & - & $2.1 \pm 3.1$ & $28.6 \pm 2.5$ & 0.948 & $16.4 \pm 0.3$ & 0.31 & 0.911 \\
\hline & - & $\mathrm{Cu}^{2+}$ & - & - & $1.2 \pm 1.1$ & $12.2 \pm 1.1$ & 0.968 & $29.4 \pm 0.9$ & 0.45 & 0.862 \\
\hline & $\mathrm{Cr}^{3+}$ & $\mathrm{Cr}^{3+}+\mathrm{Cu}^{2+}$ & 0.28 & 0.36 & $5.8 \pm 2.1$ & $11.5 \pm 2.8$ & 0.977 & $11.8 \pm 2.4$ & 0.68 & 0.985 \\
\hline & $\mathrm{Cr}^{3+}$ & $\mathrm{Cr}^{3+}+\mathrm{Pb}^{2+}$ & 0.25 & 0.35 & $4.9 \pm 0.9$ & $11.2 \pm 2.4$ & 0.982 & $10.5 \pm 2.7$ & 0.79 & 0.945 \\
\hline & $\mathrm{Pb}^{2+}$ & $\mathrm{Pb}^{2+}+\mathrm{Cu}^{2+}$ & 0.45 & 0.35 & $2.3 \pm 2.5$ & $10.1 \pm 1.9$ & 0.978 & $7.98 \pm 0.9$ & 0.61 & 0.930 \\
\hline & $\mathrm{Pb}^{2+}$ & $\mathrm{Pb}^{2+}+\mathrm{Cr}^{3+}$ & 0.50 & 0.27 & $2.0 \pm 1.6$ & $7.69 \pm 2.1$ & 0.974 & $8.23 \pm 1.4$ & 0.84 & 0.951 \\
\hline & $\mathrm{Cu}^{2+}$ & $\mathrm{Cu}^{2+}+\mathrm{Pb}^{2+}$ & 0.23 & 0.92 & $2.1 \pm 3.4$ & $11.2 \pm 3.7$ & 0.977 & $6.75 \pm 2.4$ & 0.49 & 0.933 \\
\hline & $\mathrm{Cu}^{2+}$ & $\mathrm{Cu}^{2+}+\mathrm{Cr}^{3+}$ & 0.11 & 0.44 & $2.2 \pm 2.4$ & $5.32 \pm 2.1$ & 0.981 & $3.25 \pm 1.1$ & 0.53 & 0.962 \\
\hline & & & & & \multicolumn{3}{|c|}{ Langmuir } & \multicolumn{3}{|c|}{ Freundlich } \\
\hline \multirow[t]{10}{*}{ GARo } & & & & & $b$ & $Q_{\max }$ & $r^{2}$ & $k_{F}$ & $n$ & $r^{2}$ \\
\hline & - & $\mathrm{Cr}^{3+}$ & - & - & $2.8 \pm 2.1$ & $10.4 \pm 1.9$ & 0.986 & $30.5 \pm 0.7$ & 0.59 & 0.947 \\
\hline & - & $\mathrm{Pb}^{2+}$ & - & - & $1.1 \pm 0.7$ & $9.37 \pm 2.4$ & 0.965 & $11.7 \pm 0.9$ & 0.62 & 0.932 \\
\hline & - & $\mathrm{Cu}^{2+}$ & - & - & $0.8 \pm 2.4$ & $6.85 \pm 2.1$ & 0.956 & $18.9 \pm 1.1$ & 0.51 & 0.921 \\
\hline & $\mathrm{Cr}^{3+}$ & $\mathrm{Cr}^{3+}+\mathrm{Cu}^{2+}$ & 0.39 & 0.96 & $4.1 \pm 0.9$ & $9.98 \pm 0.9$ & 0.910 & $12.1 \pm 2.2$ & 0.91 & 0.942 \\
\hline & $\mathrm{Cr}^{3+}$ & $\mathrm{Cr}^{3+}+\mathrm{Pb}^{2+}$ & 0.33 & 0.97 & $3.9 \pm 2.1$ & $10.1 \pm 3.9$ & 0.936 & $10.0 \pm 3.1$ & 0.47 & 0.961 \\
\hline & $\mathrm{Pb}^{2+}$ & $\mathrm{Pb}^{2+} \mathrm{Cu}^{2+}$ & 0.61 & 0.94 & $2.2 \pm 1.6$ & $8.85 \pm 2.5$ & 0.961 & $7.13 \pm 4.0$ & 0.45 & 0.935 \\
\hline & $\mathrm{Pb}^{2+}$ & $\mathrm{Pb}^{2+}+\mathrm{Cr}^{3+}$ & 0.74 & 0.39 & $2.8 \pm 3.1$ & $3.65 \pm 4.4$ & 0.971 & $8.62 \pm 3.1$ & 0.81 & 0.956 \\
\hline & $\mathrm{Cu}^{2+}$ & $\mathrm{Cu}^{2+}+\mathrm{Pb}^{2+}$ & 0.49 & 0.69 & $3.9 \pm 1.7$ & $4.65 \pm 3.6$ & 0.969 & $9.32 \pm 3.5$ & 0.79 & 0.962 \\
\hline & $\mathrm{Cu}^{2+}$ & $\mathrm{Cu}^{2+}+\mathrm{Cr}^{3+}$ & 0.47 & 0.33 & $2.4 \pm 3.2$ & $2.29 \pm 4.3$ & 0.983 & $8.91 \pm 2.6$ & 0.81 & 0.978 \\
\hline
\end{tabular}

\subsection{Sorption Kinetics}

Adsorption capacities of metal ions were measured as a function of time $(0-400 \mathrm{~min})$ while keeping the initial concentration, adsorbent dosage and/or sorbent-solution ratio, temperature and $\mathrm{pH}$ constant at $100 \mathrm{mg} / \mathrm{L}, 1 \mathrm{~g} / \mathrm{L}$, $25 \pm 2{ }^{\circ} \mathrm{C}$ and $\mathrm{pH}=6.5 \pm 0.02$, respectively. The results showed two contrasting adsorption processes among the two soil types. In GARo, sorption was two phased, in which the initial phase was characterized by a fast sorption process in the first 200 minutes followed by a slow sorption process. This suggests that availability of sorption sites on solid phases significantly influenced the sorption process. Conversely, the sorption process in ALVv was linear, in which sorption increased with time duration, suggesting that time was a limiting factor in the sorption process. 
$\diamond \mathrm{Cr} \times \mathrm{Pb} * \mathrm{Cu}$

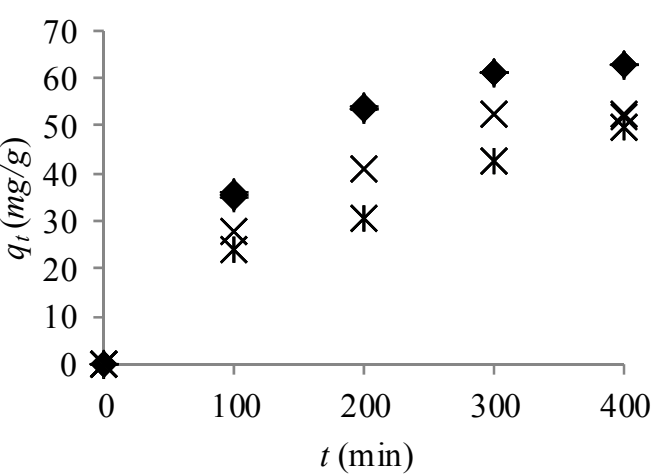

(a) Vertic-Luvisol $\diamond \mathrm{Cr} \times \mathrm{Pb} * \mathrm{Cu}$

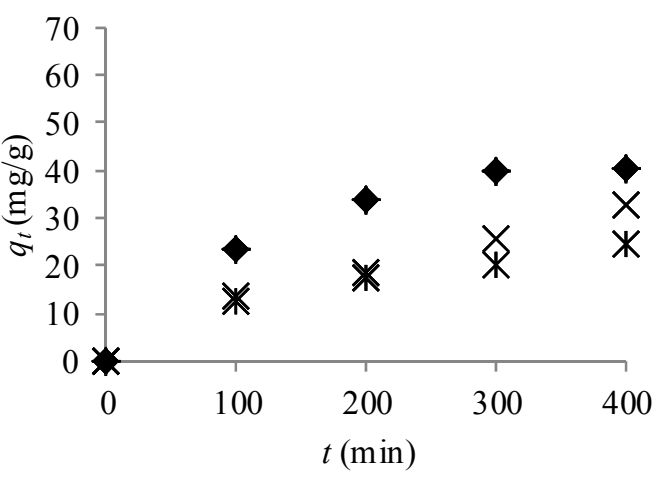

(b) Ferralic-Arenosol

Figure 5. Effect of equlibration time on adsorption of $\mathrm{Cr}^{3+}, \mathrm{Pb}^{2+}$ and $\mathrm{Cu}^{2+}$ on (a) $\mathrm{ALVv}$ and (b) GARol. The $\mathrm{pH}$ was held constant at $\mathrm{pH}=6.05 \pm 0.2$, metal ions concentrations held constant at $100 \mathrm{mg} \mathrm{L}^{-1}$ and working temperature at $25^{\circ} \mathrm{C}$

The kinetic parameters for modeling adsorption of $\mathrm{Cr}^{3+}, \mathrm{Pb}^{2+}$ and $\mathrm{Cu}^{2+}$ ions by the soil types of interest are shown in Table 5. In both soil types, the sorption kinetics of the metal ions followed pseudo-second order as shown by $r^{2} \geq 994$.

\section{Discussion}

\subsection{Comparison of Sorption Processes Based on Isothermal Plots}

\subsubsection{Monometal System}

The graphical illustrations of sorption isotherms for single metal systems showed that an increase in metal ion concentration resulted in an increase in overall adsorption (Figure 3). Moreover, metal-wise comparison of isothermal plots for the soil types showed a general preference of sorption for $\mathrm{Cr}^{3+}$ over $\mathrm{Pb}^{2+}$ and $\mathrm{Cu}^{2+}$. This is in agreement of Irha, Steinnes, Kirso, and Petrsell (2009) along with de Matos, Fontes, da Costa and Martinez, (2001) who found that adsorption of metallic ions to solid phases favoured trivalent ions over divalent ions. This preferential trend of sorption described above was similar for both soil types. However, higher sorption amounts per metallic ion $\left(Q_{e}\right)$ were achieved in $\operatorname{ALVv}\left(\mathrm{Cr}^{3+}, 11 \mathrm{mg} / \mathrm{g} ; \mathrm{Pb}^{2+}, 8 \mathrm{mg} / \mathrm{g} \mathrm{\&} \mathrm{Cu}^{2+}, 7 \mathrm{mg} / \mathrm{g}\right)$ than GARo $\left(\mathrm{Cr}^{3+}, 8\right.$ $\mathrm{mg} / \mathrm{g} ; \mathrm{Pb}^{2+}, 7 \mathrm{mg} / \mathrm{g} \& \mathrm{Cu}^{2+}, 6 \mathrm{mg} / \mathrm{g}$ ). Notably, a series of salient points were observed on isothermal plots when the concentration of equilibrated metal ions increased in the ranges $0-5,10-20$, and $25-40 \mathrm{mg} / \mathrm{L}$ for ALVv and $0-2.5,5-10$, and $10-20 \mathrm{mg} / \mathrm{L}$ for GARo, respectively. As expected, the results revealed an important underlying role of soil type on sorption i.e soil properties such as specific surface area of clay particles as well as cation exchange capacity were influential in determining sorption process of metal ions. de Matos et al. (2001) demonstrated the influence of soil properties on sorption processes of pollutants. Thus, ALVv with superior soil properties (Table 2) had higher metal loading capacity than its counterpart.

Furthermore, augmentation of metal ions in contact with the solid phases resulted in a significant acidification of the system (Figure 4). Soil-wise comparison showed that adsorption-induced acidity was more pronounced in ALVv than GARo. The acidification of the equilibrium solutions observed during the sorption of metallic ions by the solid phases is usually explained by the displacement of $\mathrm{H}^{+}$in favour of multivalent $\mathrm{M}^{2+} \beta^{+}$ions (Bradl, 2004). Thus, the adsorbent surface was dominated by negative charges that attracted positively charged metallic ions. It is widely reported that the surface charges on most clay crystals emanate from hydroxyl $(\mathrm{OH})$ groups (Adebowale et al., 2006; Bradl, 2004), however this study did not measure any Infra-Red (IR)-related parameters to identify functional groups.

\subsection{Isothermal Data Fitting}

\subsubsection{Langmuir Model}

Experimental data showed that the Langmuir model had a slightly higher correlation coefficient for linearity and conclusively suggested that it was reliable and valid in modelling sorption data of $\mathrm{Cr}^{3+}, \mathrm{Pb}^{2+}$ and $\mathrm{Cu}^{2+}$ in both soils. An isothermal soil-wise comparison based on Langmuir parameter, $Q_{\max }$ (maximum adsorption capacity 
per unit mass of adsorbent) showed higher cumulative sorption of metal ions by ALVv than GARo (Table 3). It seems reasonable to link higher retention capacities of metal ions to cation exchange capacity (CEC) and particle specific surface area, values of which were greater in ALVv than GARo. Studies by Appel et al. (2008), Bradl (2004) and de Matos et al. (2001) demonstrated that heavy metal loading capacity is correlated to high specific surface area of clay particles. Metal-wise comparison based on Langmuir parameter $Q_{\max }$ established a higher sorption capacity for $\mathrm{Cr}^{3+}$ than $\mathrm{Pb}^{2+}$ and $\mathrm{Cu}^{2+}$. The preferential-sorption of metal ions based on $Q_{\max }$ can be ordered into $\mathrm{Cr}^{3+}>\mathrm{Pb}^{2+}>\mathrm{Cu}^{2+}$ for the two soils. This adsorption sequence was similar for the two soils and did not reveal any underlying soil based variability amongst the soil types. This decisively suggested that the sorption process was driven by factors other than the expected soil properties.

The Langmuir parameter $b$, characterizing the binding strength between metal ions and functional centres on the sorption surface showed higher values for ALVv than GARo (Table 3). This could be ascribed to a series of cationic properties notably, the differences in the first hydrolysis constant $\left(\mathrm{pK}_{h}\right)$ amongst metal ions. According to Bradl (2004), ion exchange prefers cations with low a $\mathrm{pK}_{h}$, thus $\mathrm{Cr}^{3+}$ with the lowest $\mathrm{pK}_{h}$ value sorbed more than other metal ions. The same sorption trend was reported by Merdy, Gharbi, and Lucas (2009) and Fonseca, Figueiredo, Rodrigues, Queiroz, and Tavares (2011) with the former attributing the trend to the conventional hard-soft-acid-base (HSAB) principle. The hard ions are those with low polarizability and small ionic size and prefer hard ligands and form weak complexes with them. On the other hand, soft ions have greater affinity for soft sites and are more strongly bounded (Sposito, 1984).

\subsubsection{Freundlich Model}

Based on the Freundlich coefficient $k_{F}$, related to the metal ion's affinity to the solid phase, sorption of metals were ordered into the following sequence: $\mathrm{Cr}^{3+}>\mathrm{Pb}^{2+}>\mathrm{Cu}^{2+}$ for the both soils. Thus, $k_{F}$ values did not unearth any sorption variabilities between the two soils. However, the values were higher in ALVv than GARo and in each instance $\mathrm{Cr}^{3+}$ was twice higher than $\mathrm{Pb}^{2+}$ which in turn was twice higher than $\mathrm{Cu}^{2+}$. Likewise, the Freundlich adsorption intensity constant, $n$ for the metal ions and soils under study did not show any variability, except that all values were less than 1.

\subsection{Effect of Cationic Competition on Sorption}

\subsubsection{Binary-Metal System}

To investigate the overall competitive effect on sorption by metal ions, CACRs were developed based on the sorption model that had the best fit of experimental data which turned out to be the Langmuir equation (Table 4). The Langmuir-derived CACRs showed an overall suppressive effect of competition on sorption (Zhu et al., 2012). For instance, in ALVv, the total and/or cumulative sorption amount in non-competitive system was $\Sigma Q_{\max }$ $\left(\mathrm{Cr}^{3+}, \mathrm{Pb}^{2+}, \mathrm{Cu}^{2+}\right)=73.0 \mathrm{mg} / \mathrm{kg}$ which was significantly higher than the total sorbed amount in the binary-metal (competitive) system, $\Sigma Q_{\max }\left(\mathrm{Cr}^{3+}-\mathrm{Cu}^{2+}, \mathrm{Cr}^{3+}-\mathrm{Pb}^{2+}, \mathrm{Pb}^{2+}-\mathrm{Cu}^{2+}, \mathrm{Pb}^{2+}-\mathrm{Cr}^{3+}, \mathrm{Cu}^{2+}-\mathrm{Pb}^{2+}, \mathrm{Cu}^{2+}-\mathrm{Cr}^{3+}\right)=57.0 \mathrm{mg} / \mathrm{kg}$. In contrast, the total sorbed amount in GARo was higher in binary-metal system than in single-metal (non-competitive) system, where $\Sigma Q_{\max }\left(\mathrm{Cr}^{3+}, \mathrm{Pb}^{2+}, \mathrm{Cu}^{2+}\right)=26.2 \mathrm{mg} / \mathrm{kg}$ for monometal system and $\Sigma Q_{\max }$ $\left(\mathrm{Cr}^{3+}-\mathrm{Cu}^{2+}, \mathrm{Cr}^{3+}-\mathrm{Pb}^{2+}, \mathrm{Pb}^{2+}-\mathrm{Cu}^{2+}, \mathrm{Pb}^{2+}-\mathrm{Cr}^{3+}, \mathrm{Cu}^{2+}-\mathrm{Pb}^{2+}, \mathrm{Cu}^{2+}-\mathrm{Cr}^{3+}\right)=39.5 \mathrm{mg} / \mathrm{kg}$ for binary metal system. Metal-wise comparison within a soil type showed that in all cases where $\mathrm{Cr}^{3+}$ co-existed with the other metal in solution, it exerted suppressive effect on the other competing metal. This suppressive effect was substantiated by the CACR of less than 1 in all such cases (antagonistic effect of coexisting species). For instance in the $\mathrm{Cr}^{3+}-\mathrm{Cu}^{2+}$ and $\mathrm{Cr}^{3+}-\mathrm{Pb}^{2+}$ combinations in $\mathrm{ALVv}$, the $Q_{\max }$ for $\mathrm{Cr}^{3+}$ as the target analyte was 11.5 and $11.2 \mathrm{mg} / \mathrm{kg}$ in the former and latter combinations, compared to 5.32 and $7.69 \mathrm{mg} / \mathrm{kg}$ for $\mathrm{Cu}^{2+}$ and $\mathrm{Pb}^{2+}$, respectively. Furthermore, the suppressive effect of $\mathrm{Cr}^{3+}$ over other competing metal ions was manifested in GARo. In similar binary-metal combination systems $\left(\mathrm{Cr}^{3+}-\mathrm{Cu}^{2+} \& \mathrm{Cr}^{3+}-\mathrm{Pb}^{2+}\right)$, the $Q_{\max }$ for $\mathrm{Cr}^{3+}$ as the target analyte were 9.98 and $10.1 \mathrm{mg} / \mathrm{kg}$ for the former and latter combinations, respectively. While the $Q_{\max }$ for $\mathrm{Pb}^{2+}$ and $\mathrm{Cu}^{2+}$ under similar ionic combinations were 3.65 and $2.29 \mathrm{mg} / \mathrm{kg}$, respectively. Ionic charge and/or metal ion's oxidation state seemed have been the main driver of the competitive adsorption process in a binary-metal system (Irha et al., 2009; de Matos et al., 2001). The ionic charge favoured $\mathrm{Cr}^{3+}$ over $\mathrm{Pb}^{2+}$ and $\mathrm{Cu}^{2+}$, hence the observed suppressive effect (Antoniadis et al., 2007). Summarily, the suppressive effect of competition for adsorption was more emphatic in ALVv than GARo.

\subsection{Sorption Kinetics}

The time dependence of metal ion's sorption on solid phases of the two soil types is shown in Figure 5. In $A L V v$, the sorption process was biphasic, a phenomenon attributable to sorption to sites of variable reactive and/or diffusion limited sorption (Covelo et al., 2004). The shape of the curve was linear, suggesting that the sorption process increased with time. This observation is in line with existing information that bioaccumulation 
of heavy metals in terrestrial ecosystems is time dependent (Usman, 2008). The longer the period of exposure of a body of soil to heavy metals, the higher the chances of heavy metal loading beyond toxic threshold levels (Appel et al., 2008). In GARo, the fast sorption process was terminated at the $200^{\text {th }}$ minute, followed by a rather progressively slow sorption as shown by the shape of plot which reached a well-defined plateau. Soil-wise comparison based on amount of metal ions adsorbed per unit time showed that ALVv attained higher metal ion adsorption capacities than GARo. The environmental implications derived from the results indicate that the sorption process in ALVv was infinite and progressive with time rendering this soil type prone to pollution. Conversely, the sorption process in GARo was terminal and significantly influenced by availability of sorption sites on solid phases. However, metal-wise comparison showed a similar adsorption preference for metal ions in both soils, thus both soils had significant affinity for $\mathrm{Cr}^{3+}, \mathrm{Pb}^{2+}$ and $\mathrm{Cu}^{2+}$ in that order.

The kinetic parameters for sorption of metal ions by the soil types of interest are shown in Table 6. Based on superiority of correlation coefficient for linearity, $r^{2}$ the pseudo-second-order rate equation was more suited to illustrate the kinetic processes of the three heavy metal ions onto the two soil types. The pseudo-second order model is based on the assumption that the rate-determining step is a chemical sorption involving valence force through sharing of electrons between adsorbent and adsorbate (Sposito, 1984; Bradl, 2004; Mohan, Singh, \& Singh, 2006; Wu, Zhang, Guo, \& Huang, 2008). As mentioned earlier, the kinetic sorption of the metallic ions onto solid phases was characteristically biphasic - a fast initial sorption followed by a much slower and gradual sorption. This two-step kinetic process is characteristic to the heterogeneity of the surface binding sites on sorbent, explaining that different binding sites had different binding affinities to metal ions and resulted in different binding rates ( $\mathrm{Wu}$ et al., 2008). This assertion was corroborated by the Environmental Scanning Electron Microscope/EDAX micrographs (Figures 2 and 3) which highlighted the differences in morphology of the clay particles of the two soil types.

\section{Conclusion}

Sorption characteristics of selected heavy metals on soil were used as a yardstick to uncover inherent soil type variabilities amongst two semi-arid soils. The equilibrium sorption data of both soils was fittable to the Langmuir model and therefore fell short of revealing any variabilities amongst the two soil types. Nonetheless, the model was efficacious in identifying $A L V v$ as a soil type having a higher heavy metal loading capacity potential $\left(Q_{\max }\right)$ than its counterpart (GARo). Furthermore, metal ion's affinity for the solid phases were similar for both soils and assumed the order; $\mathrm{Cr}^{3+}>\mathrm{Pb}^{2+}>\mathrm{Cu}^{2+}$ and therefore inconvenient in exposing any sorption discrepancies amongst the soil types. However, preferential sorption of heavy metal onto soils was found to be driven by factors other than the expected soil type i.e cationic properties such as first hydrolysis constant $\left(\mathrm{pK}_{h}\right)$, oxidation state and/or cationic charge etc. Metal-wise competition for sorption sites was confirmed using CACRs and showed $\mathrm{Cr}^{3+}$ to have a tendency to suppress sorption of other competing entities, a feature attributable to cationic properties. When in coexistence with another competing species, $\mathrm{Cr}^{3+}$ suppressed sorption of $\mathrm{Pb}^{2+}$ and $\mathrm{Cu}^{2+}$ by up to half. The adsorption kinetics of metallic species onto the two soil types followed the pseudo-second order.

\section{Acknowledgements}

The lead author gratefully acknowledges the Postgraduate Research Scholarship from University of Botswana. Gratitude is also extended to the Department of Chemistry, University of Botswana for availing laboratory space and analytical instruments.

\section{References}

Adebowale, K., Unuabonah, I., \& Olu-Owalabi, I. (2006). The effect of some operating variables on the adsorption of lead and cadmium ions on kaolinite clay. Journal of hazardous Materials, B134, 130-139. http://dx.doi.org/10.1016/j.jhazmat.2005.10.056

Altin, O., Ozbelge, H., \& Dogu, T. (1998). Use of general purpose adsorption isotherms for heavy metal-clay mineral interactions. Journal of Colloid and Interface Science, 198(1), 130-140. http://dx.doi.org/10.1006/jcis.1997.5246

Alumaa, P., Kirso, U., Petersell, V., \& Steinnes, E. (2002). Sorption of toxic heavy metals to soil. International Journal of Hygiene and Environmental Health, 204(5-6), 375-376. http://dx.doi.org/10.1078/1438-4639-00114

Antoniadis, V., Tsadilas, C., \& Ashworth, D. (2007). Monometal and competitive adsorption of heavy metals by $\begin{array}{lllll}\text { sewage } & \text { sludge-amended } & \text { soil. } & \text { Chemosphere, } & 68(3),\end{array}$ http://dx.doi.org/10.1016/j.chemosphere.2006.12.062 
Appel, C., Ma, L., Rhue, R., \& Reve, W. (2008). Sequential sorption of lead and cadmium in three tropical soils. Environmental Pollution, 155(1), 132-140. http://dx.doi.org/10.016/j.envpol.2007.10.026

Argun, M., Dursun, S., Ozdemir, C., \& Karatas, M. (2007). Heavy metal adsorption by modified oak sawdust: Thermodynamics and kinetics. Journal of Hazadius Materials, 141(1), 77-85. http://dx.doi.org/10.1016/j.jhazmat.2006.06.095

Bolster, C. H., \& Hornberger, G. M. (2007). On the use of linearized Langmuir equations. Soil Science Society of America Journal, 71(6), 1796-1806. http://dx.doi.org/10.2136/sssaj2006.0304

Bradl, H. (2004). Adsorption of heavy metals ions on soil and soil constituents. Journal of Colloid and Interface Science, 277(1), 1-18. http://dx.doi.org/10.1016/j.jcis.2004.04.005

Covelo, E., Andrade, M., \& Vega, F. (2004). Heavy metal adsorption by humic umbrisols: selectivity sequences and competitive sorption kinetics. Journal of Colloid and Interface Science, 280(1), 1-8. http://dx.doi.org/10.1016/j.jcis.2004.07.024

de Matos, A., Fontes, M., da Costa, L., \& Martinez, M. (2001). Mobility of heavy metals as related to soil chemical and mineralogical characteristics of Brazilian soils. Environmental Pollution, 111, 429-435. http://dx.doi.org/10.1016/S0269-7491(00)00088-9

Dikinya, O., \& Areola, O. (2010). Comparative analysis of heavy metal concentration in secondary treated wastewater iirigated soils cultivated by diffrent crops. International Journal of Environmental Science and Technology, 7(2), 337-346. http://dx.doi.org/10.1007/BF03326143

Echeverria, J., Morera, M., Mazkiaran, C., \& Garido, J. (1998). Competitive sorption of heavy metals by soils: Isotherm and Factorial experiments. Environmental Pollution, 101(2), 275-284. http;//dx.doi.org/10.1016/S0269-7491(98)00038-4

FAO/ISRIC/ISSS. (1998). World References Base for Soil Resources. FAO, Rome.

Fonseca, B., Figueiredo, H., Rodrigues, J., Queiroz, A., \& Tavares, T. (2011). Mobility of Cr, Pb, Cd, Cu and Zn in a loamy sand soil: A comparative study. Geoderma, 164(3-4), 232-237. http://dx.doi.org/10.1016/j.geoderma.2011.06.016

Ghorbel-Abid, I., \& Trabeisi-Ayadi, M. (2011). Competitive adsorption of heavy metals on local landfill clay. Arabian Journal of Chemistry, in press. http://dx.doi.org/10.1016/j.arabjc.2011.02.030

Giles, C., McEvan, T., Nakhawa, S., \& Smith, S. (1960). Studies in adsorption Part XI. A system of classification of solution adsorption isotherms, and its use in diagnosis of adsorption mechanisms and in measurement of specific surface areas of solids. Journal of the Chemical Society, 5, 3973-3993. http://dx.doi.org/10.1039/jr9600003973

Gomes, S., Cavaco, S., Quina, M., \& Gando-Ferreira, L. (2010). Nanofiltration process for separating Cr(III) from acid solutions: Experimental and Modeling Analysis. Desalination, 254(1-3), 80-89. http://dx.doi.org/10.1016/j.desal.2009.12.010

Hartemink, A., \& Huting, J. (2008). Land Cover, Extent, and Properties of Arenosols in Southern Africa. Aris Land Research and Management, 22, 134-147. http://dx.doi.org/10.1080/15324980801957689

Hinz, C. (2001). Description of sorption data with isotherm equations. Geoderma, 99(3-4), 225-243. http://dx.doi.org/10.1016/S0016-7061(00)00071-9

Hinz, C., Gaston, L., \& Selim, H. (1994). Effect of sorption isotherm type on predictions of solute mobility in soil. Water Resources Research, 30(11), 3013-3021. http://dx.doi.org/10.1029/94WR01728

Irha, N., Steinnes, E., Kirso, U., \& Petersell, V. (2009). Mobility of Cd, Pb, Cu, and Cr in some Estonian soil types. Estonian Journal of Earth Sciences, 58(3), 209-214. http://dx.doi.org/10.3176/earth.2009.3.05

Javaid, A., Bajwa, R., Shafique, U., \& Anwar, J. (2011). Removal of heavy metals by adsorption on Pleurotus ostreatus. Biomass and Bioenergy, 35(5), 1675-1682. http://dx.doi.org/10.1016/j.biombioe.2010.12.035

Limousin, G., Gaudet, J. P., Charlet, S., Szenknect, S., Barthes, V., \& Krimissa, M. (2007). Sorption Osotherma: A review on physical bases, modeling and measurement. Applied Geochemistry, 22(2), 249-275. $\mathrm{http}: / / \mathrm{dx}$.doi.org/10.1016/j.apgeochem.2006.09.010

Mahamadi, C., \& Nharingo, T. (2010). Competitive adsorption of $\mathrm{Pb}^{2+}, \mathrm{Cd}^{2+}$ and $\mathrm{Zn}^{2+}$ ion onto Eichlornia crasspes in binary and ternary systems. Bioresource Technology, 101(3), 859-864. http://dx.doi.org/10.1016/j.biortech.2009.08.097 
Merdy, P., Gharbi, L., \& Lucas, Y. (2009). Pb, $\mathrm{Cu}$ and $\mathrm{Cr}$ interactions with soil: sorption experiments and modeling. Colloids and Surfaces A: Physicochemical and Engineering Aspects, 347(1-3), 192-199. http://dx.doi.org/10.1016/j.colsurfa.2009.04.004

Mohan, D., Singh, K., \& Singh, V. (2006). Trivalent chromium removal from waste water using low cost activated carbon derived from agricultural waste material and activated carbon fabric cloth. Journal of Hazardous Materials, 135(1-3), 280-295. http://dx.doi.org/10.1016/j.jhazmat.2005.11.075

Moroke, T. S., Dikinya, O., \& Patrick, C. (2009). Comparative assessment of water infiltration of soils under different tillage systems in eastern Botswana. Physics and Chemistry of the Earth, 34(4-5), 316-323. http://dx.doi.org/10.1016/j.pce.2008.002

Mosekiemang, T., \& Dikinya, O. (2012). The efficiency of chelating agents in retaining sludge-borne heavy metals in intensively applied agricultural soils. International Journal of Environmental Science and Technology, 9(1), 129-134. http://dx.doi.org/10.1007/s13762-011-0006-6

Qin, F., Wen, B., Shan, X., Xie, Y., Liu, T., Zhang, S., \& Shahamat, U. K. (2006). Mechanisms of competitive adsorption of $\mathrm{Pb}, \mathrm{Cu}$, and $\mathrm{Cd}$ on peat. Environmental Pollution, 144(2), 669-680. http://dx.doi.org/10.1016/j.envpol.2005.12.036

Rybicka, E., Calmano, W., \& Breeger, A. (1995). Heavy metals sorption/desorption on competiting clay minerals; an experimental study. Applied Clay Science, 9(5), 369-381. http://dx.doi.org/10.1016/0169-1317(94)00030-T

Sipos, P., Nemeth, T., Kis, V., \& Mohai, I. (2009). Association of individual soil mineral constituents and heavy metals as studied by sorption experiments and analytical electron microscopy analyses. Journal of Hazardous Materials, 168(2-3), 1512-1520. http://dx.doi.org/10.1016/j.jhazmat.2009.03.033

Sposito, G. (1984). The Surface Chemistry of Soils. Oxford: Oxford University Press.

Usman, A. (2008). The relative adsorption selectivities of $\mathrm{Pb}, \mathrm{Cu}, \mathrm{Zn}, \mathrm{Cd}$, and $\mathrm{Zn}$ by soils developed on shale in New Valley, Egypt. Geoderma, 144(1-2), 334-343. http://dx.doi.org/10.1016/j.geoderma.2007.12.004

Wahba, N., \& Zaghloul. (2007). Adsorption characteristics of some heavy metals by some soil minerals. Journal of Applied Sciences Research, 3(6), 421-426.

Wu, Y., Zhang, S., Guo, X., \& Huang, H. (2008). Adsorption of chromium (III) on lignin. Bioresource Technology, 99(16), 7709-7715. http://dx.doi.org/10.1016/j.biortech.2008.01.069

Zhu, Y., Hu, J., \& Wang, J. (2012). Competitive adsorption of $\mathrm{Pb}(\mathrm{II}), \mathrm{Cu}(\mathrm{II})$ and $\mathrm{Zn}$ (II) onto xanthate-modified magnetic chitosan. Journal of Hazardous Materials, 221-222, 155-161. http://dx.doi.org/10.1016/j.jhazmat.2012.04.026

\section{Copyrights}

Copyright for this article is retained by the author(s), with first publication rights granted to the journal.

This is an open-access article distributed under the terms and conditions of the Creative Commons Attribution license (http://creativecommons.org/licenses/by/3.0/). 